\title{
Are the employees in charitable organizations satisfied with their job context?
}

\author{
The case of Sri Lankan charitable institutes
}

\author{
NHK Cooray \\ Dept.of Business Management \\ Rajarata University of Sri Lanka \\ Mihinthale, Sri Lanka \\ hiru.kaushi@gmail.com \\ DMMI Dissanayake \\ Dept.of Tourism and Hospitality Management \\ Rajarata University of Sri Lanka \\ Mihinthale, Sri Lanka \\ maheshikarus1@gmail.com \\ DOI: 10.31364/SCIRJ/v6.i9.2018.P0918561 \\ http://dx.doi.org/10.31364/SCIRJ/v6.i9.2018.P0918561
}

\begin{abstract}
Job satisfaction becomes a major research interest in recent for all types of organizations and businesses. This study examines the job satisfaction of the employees work in charitable organizations in Sri Lanka. Hundred employees who are working in charitable organizations around the country have been completed the measurers of job satisfaction. Job Descriptive Index (JDI), a five scale measure of job satisfaction has been applied. The study has been utilized the primary as well as the secondary data and both descriptive and inferential tools have been used in analyzing the data. The results indicate that only the opportunities for promotions, and satisfaction with co-workers have a significant impact on the job satisfaction of the employees in charitable organizations in Sri Lanka.
\end{abstract}

IndexTerms-Charitable Organizations, Job Descriptive Index, Job Satisfaction

\section{INTRODUCTION}

Research studies on job satisfaction is one of the most discussed, written and lectured topics today with the development of the contemporary management thoughts (Ismail \&Razak, 2016). It is truer, in the context of charitable organizations the same context has been emphasized (Boezeman\&Ellemers, 2009). The primary objective of establishing charitable organizations is to serve both society and individuals (Drucker, 1990) The activities of charitable organizations began to affect almost all aspects of the society through providing services, community involvement, or volunteerism during the 1980's (Hall, 1994).

Charitable organizations account for a significant and increasing share of generating employment opportunities in an economy (Benz, 2005). Charitable organizations often have an ideological perception on how a particular the service should be offered (e.g. in religion or education).

Consequently, these organizations rely on employees who are rather motivated by the vision of an organization than by profit (Rose-Ackerman, 1996). The employees work for charitable organizations are willing to contribute labor to the production of valuable public goods and services (Preston, 1989). A similar argument is made by (Drucker, 1990), stating that many individuals prefer to work for such an employer since charitable organizations are as particularly socially responsible. Further, the employees in charitable organizations believed to be intrinsically motivated, have a strong desire to produce quality service, committed to promote the vision of the organization, and donate their labor in producing public goods which are desirable for society at large (Benz, 2005). Consequently, it is accepted that the employees work in charitable organizations obtain some other kind of values from their work than just monetary reward that compensates them for their work attempt.

However, While the job satisfaction of the employees who work in profit oriented organizations are widely addressed in the academic literature, a little is known about the job satisfaction of the employees who work in charitable organizations (Gagne \&Deci, 2005) particularly in Sri Lankan context. Therefore, the main objective of conducting this study is to identify the job satisfaction of employees work in charitable organizations in Sri Lanka.

\section{LITERATURE REVIEW}

Job satisfaction is a broadly addressed issue in both individual who work in organizations and the academic literature (Crossman \&Abou-Zaki, 2003). Job satisfaction can be interpreted in different ways. Price (2001) defined that job satisfaction is the affective orientation that an employee possess towards their work. Similarly, the term Job satisfaction can be further explained as a positive feeling about individuals' occupation which obtains after evaluating the job characteristics. A person with high level of job satisfaction holds positive feeling about the job and vice versa (Robbins S. P., 2003).

However, situational theories believe that job satisfaction is influenced by the interaction of variables such as task characteristics, organizational characteristics and individual 
characteristics (Hoy \&Miskel, 1996). According to (Quarstein, McAfee, \& Glassman, 1992), employees evaluate the situational characteristics before commencing their job, whereas situational occurrences are evaluated afterwards. They further claimed that overall satisfaction is a function of a combination of both situational characteristics and situational occurrences. The situational characteristics commonly proposed as key factors in job satisfaction are: the work itself, pay, promotion, managers and co-workers (Smith, Kendall, \&Hullin, 1969). Accordingly, The Job Descriptive Index (JDI) is the most commonly used and valid measure of job satisfaction and it measures the five factors; the work itself, pay, opportunities for promotions, how satisfied the employee is with the manager's behavior, and how satisfied with his co workers. JDI has been used broadly in organizational psychology researches to measure the job satisfaction of employees and thus it is proven to be valid (Spector P. E., 2000)

Despite the fact that the organization is profit oriented or charitable, Employees' job satisfaction is at paramount important to every organization. Many researchers found that improving job satisfaction can reduce turnover and help in maintaining a stable and motivated workforce. Further, (Robbins S. P., 2003) indicated in his research that greater an employee is satisfied with his/her job, greater will be his/her job commitment. A satisfied employee is easy to be retained in the organization and help to reduce cost of recruitment of new employees.

(Denton, 2005) suggests that employees who are happy and satisfied with their jobs are more dedicated towards their work quality and are taking concern of clientele that sustain the operation. Workers who are satisfied at their workplaces show positive attitudes towards their job and they always motivated to do their job in effectively and productively.

Findings of many research studies have been revealed that the job satisfaction of the employees work in charitable organizations is often higher than the other organizations even in the presence of comparatively lower pay levels (Benz, 2005). This is further confirmed by (Light, 2002) arguing that employees in charitable organizations tend to exhibit stronger motivation and satisfaction linked to the meaningfulness of their work regardless of lower pay levels, inadequacy of manpower and resources, and excessive workloads. Further, employees are enthusiastic in "donating work" and more loyal to their organizations (Almond \& Kendall, 2000).

\section{METHODOLOGY}

The study has been designed as an applied research and used the deductive approach in identifying the study issue. The researchers have been utilizing the quantitative data for the study in which the study has been undertaken as the quantitative study. The study objective is to apply the prevailing theoretical model for the identified organizational context as the charitable institutes in Sri Lanka.

The study has been utilized both the primary as well as the secondary data in which the secondary data has been used check the construct validity of the conceptual model which has been used by the study. The primary data analysis has been undertaken as the sample survey for the purpose the researchers has been developed the self-administrated questionnaire by which the researchers has been collected the data from the target sample. As per the nature of the study population the pollution of the study is unknown as per the statistics of Sri Lanka it is having 74 approved charities in Sri Lanka (Department of Inland Revenue, Sri Lanka, 2017). At the same time interesting the study population is that the workforce in the charitable institutes in Sri Lanka which is having less statistical support. As per the labour statistics it has been identified that the $1.8 \%$ of the total workforce of Sri Lanka working in the social service sector (Department of Census and Statistics Sri Lanka, 2017). Accordingly it has been identified that the size of the study population is unknown to the researchers based on which the study has been utilized the convenient sampling as the sampling technique for the study. The study has been selected 100 respondents using the convenience base for the seven charitable institutes covering the island. Furthermore in analyzing the responded the researchers have been identified the employee who works in the charitable organization in Sri Lanka.

The study has been used the Statistical Package for Social Sciences (SPSS) in analyzing the primary data by using all the descriptive as well as inferential tools. And the hypotheses have been tested by using the multiple regression analysis. The following section of the study report elaborates the key findings of the data analysis for the study.

\section{DATA ANALYSIS}

With the collected data of 100 respondents in the sample it has been tested the reliability of the data set which has been make the higher dependability on the data which can be prove with the evidence. As per a Cronbach's Alpha value of the data set it has been identified at the level of 0.880 which is in the acceptable level. According with the (Schmitt, 1996) it has been identified the Cronbach's Alpha value which is greater than the 0.7 is considered as the reliable data set as per the data set which has been analyzed which is having Cronbach's Alpha value of 0.880 can be considered as the reliable data set.

Furthermore it has been analyzed the sample profile of the respondents to take the understanding on the nature of the respondents. This makes the effective generalization of the study findings in to the actual organizational context.Based on following table it shows the majority respondents in the survey were males. There were 23 female respondents and 77 male respondents. Although the respondents were in the range of 2030 years old which represent 21 respondents, 35 respondents' age range was between 31 - 40 years old, range of 41 - 50 years old represent 17 respondents, range of 51-60 years old represent 14 respondents and range of 60+ years old represent 13 respondents. The respondents whom are under 30 years old have 21 while above $60+$ years old have 13 respondents. This represents the tendency of an employment in Sri Lanka is an important factor in understanding the human resource capabilities and innovation capabilities in the service industry.

Majority of the respondents who worked at apparel industry with the frequency above 12 years is $35 \%$. The service period at the range 0-2-year years are $21.5 \%$ whereas period at the range 6-8-year years are $17 \%$. The period at the range 9-11year years are $14 \%$ and the period at the range 3-5-year years are $13 \%$.

Table 1: Sample Characteristics

\begin{tabular}{|l|l|l|}
\hline Characteristics & Count & \% \\
\hline Gender Male & 77 & $77 \%$ \\
Female & 23 & $23 \%$ \\
\hline
\end{tabular}




\begin{tabular}{|c|c|c|}
\hline $\begin{array}{l}\text { Age } \quad 20-30 \\
31-40 \\
41-50 \\
51-60 \\
\quad 60+\end{array}$ & $\begin{array}{l}21 \\
35 \\
17 \\
14 \\
13\end{array}$ & $\begin{array}{l}21 \% \\
35 \% \\
17 \% \\
14 \% \\
13 \%\end{array}$ \\
\hline $\begin{array}{l}\text { Tenure (Lengthof Service) } \\
0-2 \\
\begin{array}{ll}3-5 \\
6-8 \\
& 9-11 \\
12+\end{array} \\
\end{array}$ & $\begin{array}{l}21 \\
13 \\
18 \\
13 \\
35\end{array}$ & $\begin{array}{l}21 \% \\
13 \% \\
18 \% \\
13 \% \\
35 \%\end{array}$ \\
\hline
\end{tabular}

Source: Survey Data, 2018

With the understanding on the sample analysis it has been conducted the in depth inferential analysis on the data set. As per the analysis it has been observed the normality in the data set in which it has been used the parametric test in testing the study hypotheses. In statistical modeling, regression analysis is a statistical process for estimating the relationship among variables. It includes many techniques for modeling and analyzing several variables, when the focus is on the relationship between a dependent variable and one or more independent variables. More specifically, regression analysis helps one understands how the typical value of the dependent variable changes when anyone of the independent variables are held fixed. For any study it is important to check the validity of the conceptual model which has been used by the researcher in order to understand the research problem. In other wording the conceptual model should be fit to the identified problem in the study. Therefore, the researcher has check the model fit of the used conceptual model by using the regression analysis. The detailed summary of the result has been illustrated below with the objective of validating the used conceptual model by the researcher for the study. The fitness of the model explains the validity of the conceptual model used by the researcher.

Table 2: Model summery for the study

Model Summary

\begin{tabular}{|c|c|c|c|c|}
\hline $\begin{array}{c}\text { Mo } \\
\text { del }\end{array}$ & R & $\begin{array}{c}\text { R } \\
\text { Square }\end{array}$ & $\begin{array}{c}\text { Adjusted R } \\
\text { Square }\end{array}$ & $\begin{array}{c}\text { Std. Error } \\
\text { of the Estimate }\end{array}$ \\
\hline 1 & $.787 \mathrm{a}$ & .619 & .599 & .665 \\
\hline
\end{tabular}

a. Predictors: (Constant), Managers, Co_workers, Pay, Work_it_self, Promotion

Source: Developed by Author

The coefficient of determination ( $\mathrm{R}$ square) describes the contribution made by the independent variables to the variation of dependent variable. Also, the overall significance of the model can be measured using $\mathrm{R}$ square. Accordingly, the $\mathrm{R}$ square value of the study was 0.619. It indicated that the selected independent variables are capable enough to explain $61.9 \%$ variation in the dependent variable. Adjusted R square was 0.599 and it indicated that model is reasonably fitted to the data.

And the following table demonstrates the impact of the identified variables on the job satisfaction and whether the impact of the variable is significant on the job satisfaction or not.

Table 3: Coefficients of the multiple regression analysis

\begin{tabular}{|l|c|c|c|}
\hline \multicolumn{1}{|c|}{ Model } & \multicolumn{2}{|c|}{$\begin{array}{c}\text { Standardized } \\
\text { Coefficients }\end{array}$} & Sig. \\
\hline (Constant) & -.301 & .356 & .400 \\
Pay & .116 & .141 & .414 \\
Promotion & -.371 & .181 & .043
\end{tabular}

\begin{tabular}{l|l|l|l|} 
Work_it_self & .148 & .176 & .403 \\
Co_workers & 1.155 & .124 & .000 \\
Managers & .091 & .117 & .438 \\
\hline
\end{tabular}

Source: Developed by Author

Accordingly it has been highlighted the fact that only the promotion and the co-workers have the significant impact on the job satisfaction of the organizational employees. This has been evidenced that the significant value which is less than 0.05 and on the other hand out of the significant factors the most impactful factor has been identified as the c-workers. In other wordings it can be interpret as the co-worker behavior and the promotion of the organization is significantly influence on the organizational employee job satisfaction.

\section{DisCUSSION OF RESULTS}

In discussing the final results, it has been identified the main observations in the data collected. The key result can be discussed as follows,

- In the reliability test researcher found Cronbach alpha value for all variables. Under the factor analysis coefficient values of work itself is 0.81 which is considered as a very good reliability while co-workers and managers had 0.66 respectively which considered fair reliability.

- Under the descriptive statistics researcher have found descriptive statistics for pay, managers, coworkers, work itself, promotions, reward structure, work environment and job satisfaction. Researcher identified all mean values and standard deviations of dimensions of all independent variable. In here researcher identified there was some significance difference between mean values and independent variable. Researcher identified that descriptive statistics for dependent variable (job satisfaction). According to the mean value (2.9733) and standard deviation (0.76933) of job satisfaction, researcher identified majority of employees are satisfied with their job.

- Under the regression analysis researcher did simple linear regression. $\mathrm{R}$ square and adjusted $\mathrm{R}$ square of promotion, co-workers, managers, work and pay Accordingly the $\mathrm{R}$ square value of the study was 0.619. It indicated that the selected independent variables are capable enough to explain $61.9 \%$ variation in the dependent variable. Adjusted R square was 0.599 and it indicated that model is reasonably fitted to the data. Accordingly, with the model summary it explained that the model is having the $59.9 \%$ influence for the identified problem context. Also, researcher mentioned the beta values for all independent and dependent variable through the multiple linear regressions.

\section{RECOMMENDATIONS}

The recommendation will be given to increase the motivation and right attitude, where managers must seek strategies and techniques to increase the motivation of their employees and empower them with right attitude for a better service in charitable institutes in Sri Lanka.

- $\quad$ Since a small percentage indicated being dissatisfied with their Reward Structure, it is recommended that 
the pay and promotion policies and procedures be checked to ensure that they are equitable. .

- The management should have a system to know employees personally periodically since they are coming from different ethnic, religious, linguistic and cultural backgrounds.

- To mitigate the work-life balance it can be suggested that it is better to orient and inspire the employees through various orientation programmes and activities etc.

- Through various activities that improve team relationship will help both organization and employees to perform better. Such activities also will provide opportunities for employees to get more comfortable with each other.

- Most of the employees were satisfied with their working environment therefore this has to be properly maintained and strengthened further.

- Every employee should have qualifications according to his/her obligation or responsibility which will make the person self-confident in the service. Some qualifications are not properly matched with the job requirements. There should be a minimum standard for the employees.

- To improve effectiveness of the work employees should be given a proper counseling program.

- It can be recommended that it should established some program to increase the interaction between employees and management

One of the important and basic requirements in achieving the objectives is taking personal differences of employees into account and motivating them to get involved in the task.

\section{REFERENCE}

Almond, S., \& Kendall, J. (2000). Paid employement in the self defind voluntary sectorin the late 1990s: An initial description of patterns and trends. London: London School of Economics .

Benz, M. (2005). Not for the profit, but for the satisfaction ? Evidence on worker well-being in non profitfirms .KYKLOS , 155-176.

Boezeman, E., \&Ellemers, N. (2009).Intrinsic need satisfaction and the job attitudes of volunteers versus employees working in a charitable volunteer organization. Journal of Occupational and Organizational Psychology , 897914.

Crossman, A., \&Abou-Zaki, B. (2003).Job Satisfaction and Employee Performance of Lebanese Bnaking Staff. Journal of Managerial Psychology , 368-376.

Denton, Z. (2005). Effect of work and environment on homecare workers' job satisfaction, stress, physical health and retention . Canadian Health Service Research Foundation, 25.

Department of Census and Statistics Sri Lanka . (2017). Sri Lanka Labour Force Survey Annual Report 2016. Colombo: Department of Census and Statistics Sri Lanka .

Department of Inland Revenue, Sri Lanka.(2017). Department of Inland Revenue, Sri Lanka. Retrieved 09 19, 2018, from Department of Inland Revenue, Sri Lanka: http://www.ird.gov.lk/en/publications/SitePages/Approved\%20 Charity.aspx?menuid=1408

Drucker. (1990). Managing the Non Profit Organizations. New York: Harper Collins.
Gagne, M., \&Deci, E. L. (2005). Self Determination Theory and work motivation. Journal of Organizational Behaviour, 331-362.

Hall, E. (1994). Historical Percpective of Non Profit Organizations. San Francisco: Jossey Base.

Hoy, W. K., \&Miskel, C. E. (1996). Educational Administration: Theory, Research, and Practice . New York: McGraw-Hill.

Light, P. (2002). The content of their character: The state of the nonprofit workforce . Nonprofit Quarterly , 6-19.

Preston, A. (1989). The non profit worker in a for profit world . Journal of Labor Economics , 438-463.

Price, J. L. (2001). Reflection of the determinants of voluntary turnover . International Journal of Manpower , 600624.

Quarstein, V. A., McAfee, \& Glassman, R. B. (1992).The situational occurances theory of job satisfaction. Human Relations, 859-873.

Robbins, S. P. (2003). Organizational Behavior Concepts, Controversies, Application . New Jersey: Prentice Hall.

Robbins, S., \& Judge, T. (2001). Organizational behavior (Vol. 14). . New Jersey: Prentice-Hall.

Rose-Ackerman, S. (1996).Altrusim, Nonprofits, and Economic Theory. Journal of Economic Litereture , 701-728.

Smith, P. C., Kendall, L. M., \&Hullin, C. L. (1969).Mesurement of Satisfactionin Work and Retirement . Chicago: Rand McNally.

Spector, P. E. (2000). Industrial and Organizational Psychology Research and Practice. New York: John Wiley and Sons.

Spector, P. E. (1997). Job satisfaction: Application, assessment, causes, and consequences (Vol. 3). Sage publications. 